\title{
Cooperative marketing societies and its challenges for sustainable Economic Development in Lagos, Nigeria
}

\author{
Mande, Samaila Phd and Lawal Kamaldeen A. A \\ School of Management Sciences, \\ National Open University of Nigeria (NOUN), Lagos
}

\begin{abstract}
The paper notes the transformation of cooperative marketing societies, and the shortcomings inherent in the cooperative marketing operations, management which dampen their achievement and potentials to achieve sustainable economic development in Nigeria. The paper therefore, advocates for cooperative marketing and establishment of a cooperative Board/Agency, improved returns on shares, democratic and transparent leadership for cooperative societies to be able to impact significantly on the society for sustainable economic growth and development in Nigeria. Although cooperative societies in Nigeria have impacted significantly on encouraging commercial activities, savings mobilization, communal development and contributing generally to economic growth, they fill the gap created by the absence of marketing and inadequate capital or funds from the surplus-economic-units and urban areas.
\end{abstract}

Keyword: cooperative, marketing, economic, and development.

\section{Introduction}

Throughout human history some activities have always been undertaken by groups rather than individuals, simply because this was a better and more economic way of doing things. Cooperative marketing is a method of working together with others having the same or similar needs or problems. It is a method of pooling resources and human endeavour, acting in an organized, disciplined manner.

Cooperative marketing is the collaborative efforts of two or more companies working together in advertising and promotional efforts to reach the same goal. This is sometimes referred to as co-op advertising, but is also not limited to the advertising arena alone. Typically this is seen when a manufacturer supports the efforts of a retailer, but can also be used by multiple businesses looking to pool their resources to defray costs for advertising and promotion (DiBona, 2009).

Informal network of financial markets participants include money lenders, rotating savings collectors, mutual assistance groups, Self-Help Groups (SHGS) etc. the Self-Help groups have long been in existence in Nigeria as informal or semi-formal associations known in different tribes as Isusu in Igbo, Adashe in Hausa, Ajo in Yoruba, Yak'kishar in Ngas, Bam and Oku in Tiv and Kalabari Ijaw respectively, etc. These associations becomes formal institutions of credit if they are registered as cooperative societies (Mohammed, 2005). They are sub-set of the formal institutions (when registered) which cover a wide spectrum of economic activities including farming, fishing, petty trading, arts and crafts, local processing and the likes that serve as source of livelihood of millions of Nigerians living both in rural and urban areas. Of recent, Cooperative Societies have increased significantly in terms of number, membership and activities across the country. They provide a veritable source for funds mobilization and participatory credit administration in Nigeria. They are organized to mobilize savings and to channel financial resources to individual needs, largely for consumption. The Cooperative Societies are said to supplement the efforts of the formal financial institutions by mobilizing and channeling financial resources to the deficit areas (especially to the low and medium) income earners in Nigeria in both rural and urban centres. Their role in economic life of the Nigerian economy cannot be over emphasized. There is no doubt that cooperatives, which have their primary goals centred on social and economic aspect of their members and by extension the society as a whole can be employed for this purpose. Cooperatives, although established conventionally to cater strictly for the wellbeing of members have been discovered to be a veritable tool for economic progress and improved standard of living in the ever changing world.

\section{Definition and history of Cooperatives}

Scholars have defined cooperative societies in different ways. In ordinary language, the word 'cooperate' means "working together". The idea of working together is the underlying principle on which the cooperative movement is based, but in its technical sense, the word "cooperative" is narrowed down to mean a formal legally-established organization with a continuing existence based on the principle of working together.

In the1991: p300 (Webster's College Dictionary,). Define cooperative may as a business owned and controlled by the people who use its services or who work at it. The term co-operation is derived from a Latin word "cooperari" where the word (CO) means "with" and (OPERARI) means "to work". Thus co-operation 
means 'working together' so those who want to work together with some common economic objectives can form a society which is termed "Cooperative Society". It is a voluntary association of persons who work together to promote their economic interest. It works on the principle of self-help as well as mutual help. The main objective is to provide support to the members. Nobody joins a cooperative society to earn profit. People come forward as a group, pool their individual resources, utilize them in the possible manner, and derive some common benefit out of it. Basic to all these viewpoints is the issue that cooperative is based on the values of self-help, self responsibility, democracy and equality and that cooperative members believe in the ethical values of honesty, openness, social responsibility and care for one another.

A cooperative is defined by the International Cooperative Alliance as an autonomous association of persons united voluntarily to meet their common economic, social and cultural needs and aspirations through a jointly owned and democratically-controlled enterprise. Cooperative can be defined as working or acting together for a common purpose or benefit. This definition emphasizes that cooperatives are independent of government and not owned by anyone other than the members. They are united voluntarily, and should be free to join or leave. Cooperatives societies are distinguished from shareholding firms by the democratic nature, with voting rights being assigned by person rather than by size of shareholding. Besides, they are enterprises and not charities, NGOS or branches of government.

From the legal stance, Helms (1968) defined cooperative as "a registered voluntary association of persons, with membership not less than ten person with a common interest formed and operated along democratic principles, for the purpose of economic and social interest at least cost to its members who contribute the capital and manage the business so established by delegating some powers to elect management. Oludimu and Adedoyin (1996) described cooperative as the outward expression of the instinctive human solidarity and spirit of brotherhood present in every human being.

Behind these principles, are such as self-help, equity, democracy, equality among members, and solidarity. However, it also comes from practical experience that suggests that isolated cooperatives will remain economically weak, while clusters of cooperatives will gain strength networking and developing common apex organization and shared services. Olesin (2007) described the idea of cooperation to be that 'what everybody saves is pooled and members can take loans to buy households items, vehicles, lands, houses or do business, but there is a bond that the borrowers must benefit from the same pool'. Although the term may be used loosely to describe a way of working, a cooperative is a legal entity owned and democratically controlled equally by its members. The defining point in a cooperative is that the members have a close association with cooperative as producers or consumers of its products or services, or as its employees. In some countries, there are specific forms of incorporation for cooperatives, while in others they may take the form of companies limited by shares or by guarantee, partnerships or unincorporated associations.

Although co-operation as the form of individual and societal behaviour is intrinsic to human organisation, the history of modern cooperative date to the Agricultural and Industrial revolution of the $18^{\text {th }}$ and $19^{\text {th }}$ centuries. The 'first cooperative' is under some dispute, but there were various milestones which came to the fore during the late 19th century, first in Europe and later in other parts of the world. These developments took place in parallel with the development of joint-stock companies, which evolved as a means of procuring capital for corporate entities. The outcome of the growth of formal, legally recognised, organisations was the creation of many selfcontrolled and self-patronized business organisations; at the same time, various other forms of mutual enterprise also emerged. For instance, Fenwick Weavers' Society (1761) was formed in Fenwick, East Ayrshire and Scotland to sell discounted oatmeal to local workers. Its services expanded to include assistance with savings and loans, emigration and education. In 1810, Robert Owen and his partners purchased New Lanark mill from Owen's father-in-law and proceeded to introduce better labour standards including discounted retail shops where profits were passed on to his employees. Owen left New Lanark to pursue other forms of cooperative organisation and cooperative ideas through writing and lectures. Cooperative communities were then set up in Glasgow, Indiana and Hampshire, although ultimately unsuccessful. William King (1828) set up a newspaper, the Cooperator, to promote Owen's thinking, having already set up a Cooperative store in Brighton.

For many years before 1840, Rochdale a small town of about 25,000 people in Northern England, had had its economy dominated by the textile industry (with coal mining and farming as the next most common industries), and Rochdale was famous for its flannels. But as the Industrial Revolution progressed and textile production became mechanized, workers struggled to maintain the standard of living that they had known in the past. Many weavers lived in poverty; "from all around came reports of weavers clothed in rags, who had sold all their furniture, who worked 16 hours a day yet lived on a diet of oatmeal, potatoes, union porridge and treacle". No minimum wage existed and salaries were commonly below the equivalent of 10 pence per week in modern terms. Moreover, pollution had increased and public sanitation system was both poor in quality and quantity. In fact, in 1848, the mean life expectancy in Rochdale was only 21 years, six years lower than the English national average. Yet, the Rochdale Society (1844) is usually considered the first successful 
Cooperative enterprise, used as a model for modern Cooperatives following the 'Rochdale Principles'. From then on, cooperatives have been based on the values of self-help, self-responsibility, democracy and equality. Worldwide, those rules and regulations formulated and applied by the Rockdale Equitable Pioneers have become the cooperative principles for which successful and aspiring societies logically follow. These are identified as: Open membership, Democratic control, Limited interest on capital, Patronage refunds, Political and religious neutrality, Case trading at market prices, Education of members, Sales of pure and unadulterated good.

The current statement on identity, values and principles of cooperatives, was adopted in 1995 at the World Congress of the International Cooperative Alliance (ICA). The Congress endorsed a revision of the seven core cooperative principles and agreed on a basic statement of Cooperative identity for the first time. In addition, two sets of related values (basic and ethical) to underpin the principles were also agreed upon. The revision was adopted in response to the rapid changes stemming from globalisation especially trends of liberalisation and deregulation, marketisation, and political changes. The restatement was also viewed as an opportunity to promote harmonisation within the cooperative sector in providing a general framework whilst also recognizing diversity within the sector.

A second tradition with a related but separate set of cooperative principles has been developed by banking and credit cooperatives which originated from Germany and Austria during the nineteenth century. Under the leadership of Friedrich Raiffeisen, financial Cooperatives were developed in rural areas which in turn helped to promote the development of other types of cooperatives. These Cooperatives also have a global reach with a separate international apex body, the Raiffeisen Union. Raiffeisen cooperative principles are similar to the Rochdale ones. They can vary but normally include: self reliance; solidarity among members; voluntary participation; flexible organisation; self administration and internal democracy. The Rochdale and Raiffeisen principles remain the dominant ones within the Cooperative movement though other versions have been suggested. In the USA, the Department of Agriculture adopted just three principles in 1987 - those of user ownership, user control and user benefits. These relate primarily to the ICA principles which are concerned with the internal running of the Cooperative rather than any wider community role or relationships with other cooperatives. They have been utilized by the UN Guidelines on Cooperative Development in 2001, and a year later provided the basis for a new International Labour Organisation (ILO) recommendation 193 on the promotion of cooperatives. They were also cited in the European Commission in its communication on the promotion of cooperative societies in Europe in 2004. As cooperative legislation is remodelled along the lines of ILO 193, the principles are beginning to provide the basis for new Cooperative legislation in developing countries. This has been aided by the publication by the ILO of a revised version of its Guidelines for Cooperative Legislation. A stated aim is to promote harmonization of Cooperative laws so as to facilitate competitiveness of Cooperatives in the context of regional and international economic integration. The presence of financial cooperatives also varies widely - measured by the ratio of members to active population, market coverage varies from $1 \%$ in Asia to $41 \%$ in North America (Cuevas and Fischer, 2006).

In the tradition of their founders, cooperative members till today believe in the ethical values of honesty, openness, social responsibility and caring for others. Such legal entities have a range of unique social characteristics. Membership is open, meaning that anyone who satisfies certain non-discriminatory conditions may join. Economic benefits are distributed proportionally according to each member's level of economic interest in the cooperative. The emergence of a type of Cooperative reflecting the needs of more than one group of stakeholders has recently been noted with the development of social Cooperatives in Italy, for example. Educational Cooperatives which involve not just workers in the cooperative but also the users of the educational services provided are another. The reach of cooperatives is also reflected in ICA structures which are divided along sectoral lines with nine apex global bodies representing fisheries, agriculture, banking, health, housing, insurance, tourism, consumer and workers. Each apex organisation is democratically owned and financed by its member organisations. However, even within these sectors, there can still be variation in the types of Cooperative institutional form adopted. Setting aside financial cooperatives, there is a generally accepted typology of Cooperatives with four major forms: Consumer cooperatives, worker cooperatives, producer cooperatives and shared services. They operate in all sectors of the economy (Source: http://www.ncba.org/abcoop.cfm).

\section{Development of cooperative in Lagos Nigeria}

Cooperative in Nigeria started as far back as 1907. Notable among the earliest cooperative societies was Agege Planters Union (APU), made up of cocoa producers. About four hundred cocoa farmers came together to ensure that cocoa was the major farm produce earning foreign exchange for Nigeria. When this union was not immediately recognised by the government, they did not relent on their efforts. There were still other farmers unions existing elsewhere (Epetimehin, 2006: Fred, 2006). The colonial masters, with the formulation and enactment of cooperative legislation in 1935 based on the report of Mr. Strickland's stated that 
cooperative will thrive in Nigeria. He also proposed and actually drafted the relevant ordinance and regulations. Later the government saw the need to promote savings habit among the low-income people. With another report which Mr. Strickland submitted in 1936, Cooperative Thrift and Credit Societies (CTCS) were formed and it spread all over Eastern and Western Nigeria as noted by Adeyeye and Ditto (1980).

Moreso, the enactment of the ordinance saw more rapid development of Cooperative since the enabling framework has been provided. Even though some of the early Cooperatives collapsed for a number of reasons, the mistakes have been learnt a lot more was formed especially after Nigeria's independence 1960. The effort of the colonial government in spreading cooperatives was effective. From independence to the present, concerted efforts are being made to bring cooperatives to every community. As more state is created so also Cooperatives are bought nearer to the grass roots. Since the inception of cooperatives in Nigeria, government had been playing prominent and laudable roles in its development and spread. The initial achievement of the government on cooperatives was the promulgation Cooperative Laws and the Cooperative Regulations which followed on the 6th February, 1936. In 1937, Gbedun Cooperative Produce Marketing Society became the first cooperative society to be the registered in Nigeria. After these developments, several cooperative societies and union were formed and registered by the government. The Nigeria Cooperative Societies Association (NCSA) which comprises all cooperative societies in Nigeria later became Cooperative Societies Association (CSA). It is upon these solid foundation and achievement that cooperative societies in the country are building up till today and all indications point to a brighter future for cooperatives in Nigeria. A study of cooperative development throughout the world is useful for understanding the success and failure of modern cooperatives. It has been noted that cooperatives were formed where there is a felt-need but government especially in developing countries often give active support to cooperative because they promise to help the poor and to remove or reduce unfair treatment or injustice or uneven distribution of welfare. Reeves (2003) opined that the best way of pushing back the limit of economic problems of scarcity is by working together. This is because more can be accomplished when people coordinate and take concerns and talents of one another into considerations.

\section{Marketing Cooperative Societies and Economic Development in Lagos, Nigeria}

Financial Markets plays a crucial role in the financial and economic development of any economy. They act as conducts through which funds from the surplus sectors of the economy are channeled to the deficit sector for investment purposes. This fundamental role dictates the benchmark upon which the efficiency of the market is measured. The channelling of the funds in an economy is driven by the differences in the size of the fund, maturity and the risk attached to the transfer (Nnanna, 2004). The financial sector performs its roles by transforming funds in the system such that the needs of both the ultimate providers and users of funds are met. This transformation of funds is usually referred to as financial intermediation.

In Nigeria, the inability to adequately marketing channel institutional credits from the highly liquid banking system to the deficit productive or real sectors of the economy has been worrisome to both the government and monetary authorities. Banks' reluctance to lend to the real sector of the economy is borne out of the short-term nature of their rates of previous loan facilities. Expectedly, banks cannot mobilize short-term funds for long-term lending (Nnanna, 2004). Cooperative societies are almost form of organization today found in practically all countries and used by people in many ways. They provides a veritable source for funds mobilization and participatory credit administration in Nigeria. They are organized to mobilize savings and to channel financial resources to individual needs, largely for consumption (Nnanna, 2004). (lawal and Oludimu , 2012) asserted that the historical success that attended the efforts of early cooperators - "Rochdale pioneers" in Britain has given cooperative a world-wide pride of place as an instrument of economic development and social justice. Evidences have also shown that cooperative in various countries plays very important roles in sectors such as agriculture, trade and industry which contribute to economic development. Important for economic development are the democratic, social justice and education principles on which cooperative societies are based.

The cooperative movement in Nigeria has been playing enviable roles in the nation economic development in the following ways:-

1. Marketing of agricultural products: In the agricultural sector of the economy, the cooperatives have made worthwhile contributions. In western Nigeria, cooperatives were involved in the production and marketing of high quality cocoa. In the east they played a similar role with respect to palm produce while their contribution in the north had to do with marketing of groundnut and cotton (Adaji, 2000). In the area of effective dissemination of modern agricultural technology, service officers meet with members to discuss developments in agricultural techniques. Cooperatives in the industrial sector have focused on processing of agricultural products such as cassava into garri; rice milling; and weaving. 
2. Provision of credit facilities: Of recent in Nigeria, the major role of cooperatives has turned to be more concerned in the provision of credit to both rural and urban dwellers. Most of rural credit societies serve as village banks for members (Umebali, 2008). Contemporarily in Nigeria, cooperative societies are not only formed among government workers, private sectors, farmers etc, but in churches and mosques in both rural and urban areas for the purposes of providing credit needs of the community / members to purchases farm inputs (Seedlings, fertilizer, labor), pay children's / ward's school fees and other necessary social responsibilities. Many people in business who are members and sometimes non-members benefits immensely from the cooperative societies. Similarly, in the urban areas, cooperative societies have not only provided credit facilities for members for agricultural production, industrial, business, transport and communication only, but have also served as a source of credit for acquisition and development of land for housing purposes. This is as result of the high interest rate charged by the mortgage financial institutions and the inability of the poor masses collaterals for such loans. By this means, cooperative societies complement the credit roles of the mortgage financial institutions in the economy.

3. Poverty reduction: Cooperative societies are effective instruments of poverty reduction among the poor majority of the Nigerian society. Improvement of the agricultural and commercial sectors of the rural areas through the activities of cooperative societies has continued to help in reducing poverty in both the rural and urban areas thereby enhancing the standard of living of the people (Adaji, 2000). The cooperative societies are considered veritable instrument of breaking out of the vicious circle of poverty through their credit and financial obligations to their members. Members can borrow from the society to embark on worthwhile investments that can yield more profits to improve their standard of living. The loans from the cooperative societies complement their low income in financing businesses to break out of the chronic vicious circle of poverty.

4. Access to banking credit facilities: Closely related to the above, is the fact that cooperative societies efforts its members the opportunity to secure loans from the commercial banks with little or no access to bank credit facilities because of lack of collaterals may have the opportunity of borrowing from commercial banks. One way is that the cooperatives can stand as guarantors for the individuals who have made substantial contributions in the cooperative society. Another way is that the society can borrow from the commercial banks on behalf of their members and loan to the individuals according to the member's ability to pay back. This also helps individuals to finance businesses and other projects that improve the welfare of their members in the economy.

5. Curbing inflation: Inflation caused by lack of goods and services in an economy may be reduced by increased productivity in the economy. When cooperative societies lends to members at lower interest rates and when these are channeled into productive economic ventures, it will significantly increase output, thereby pulling down prices in the economy. So also, the participation of consumer cooperatives in the distribution of essential commodities which enhances the availability of goods and services plays a vital role in curbing inflation in addition to meeting the needs of their members in the economy.

6. Employment Opportunity: Cooperative societies in Nigeria also serve as a source of employment to both the skilled and unskilled labor in Nigeria. These cooperatives usually employ staffs to maintain and manage the societies on behalf of their members. For instance, Accountants, Cashiers, Clarks, Messengers, Drivers, security Personnel etc. are employed to see to the day- today smooth running of the societies. These staffs are usually paid salaries for the job they perform.

7. Contribution to socio-political development: One of the principles of cooperative is democratic control. Cooperative societies are association of persons, employees, usually of limited means who voluntarily come together on the basis of equality and equity for the enhancement of members' corporate and individual welfare (Nnanna, 2004). All members are expected to participate in the activities of their societies. Cooperatives have developed their members' political consciousness and invariably got them involved in learning basis acts of governance at the local level. Cooperatives have in this way produced community and even national leaders. They also usually make their members to imbibe the culture of prudent financing through the use of loans they obtain from the societies. Members in a cooperative society learn the culture of democratic leadership, accountability and prudential uses of their resources.

\section{Challenges of Sustainable Economic Development in Nigeria}

Marketing Cooperative societies have a role to play in the socio-economic development of Lagos, Nigeria. They, like all human enterprises, are faced with some challenges which needs attention if maximum benefit is to be derived from their operations for sustainable economic development in Lagos, Nigeria. Cooperatives in Nigeria are threatened by mounting challenges capable of hampering their effective 
performance and being one of the strategies for economic development and transformation. As observed by", Ighomereho, Dauda \& Olabisi (2012, p. 313) In their work on "Making cooperatives effective for poverty alleviation and economic development in Nigeria also highlighted some of these challenges, which range from poor governance to limited managerial skills, inadequate funding, limited access to investment credits, ineffective implementation of government policies, resistance to change, inadequate education in cooperative operations and limited marketing activities. In addition to the highlighted problems, the available human resource in the sector seems to be underdeveloped and thus lack the necessary adroitness and expertise that could make the society vibrant and fit to face global challenges. Over the years, it is not uncommon to see members of cooperatives in Nigeria aspiring to leadership position without any skill or competence for such post. More often than not, majority of them have the singular aim of what benefits might accrue to them as one of the executive members. Therefore, it is always the case to find sharp practices among such cooperative leaders. The reason for this is not far to seek, the marketing channel, essential human capital contents, the competence, dexterity and the skills they require to function appropriately in order to provide good leadership for effective performance of the sector seem to be lacking. Modern expertise is needed to reposition the sector for economic step-up and better living standard to prevent it from operating below standard.

Some of the challenges face by cooperative societies in achieving sustainable economic development in Nigeria as observed by (Ahmed, 1999). Adaji (2006), Nnanna (2004), (Mohammed, 2005), this are poor management leads to apathy among members, under-capitalization, unwilling to lend to cooperative societies because of the fear of their inability to payback, Leadership tussle.

Over the years, major changes came into effect to improve the Cooperative marketing societies. Many institution viz., the regulated markets, marketing boards, cooperative marketing institutions, warehousing cooperatives etc., have been established primarily to help the members. The various marketing functions viz., grading, standardization, storage, market intelligence, etc., could not keep pace with the technological adoptions need to be improved to meet the present day requirements of the members. In improving the marketing system for goods and services in developing countries as Nigeria, it is pertinent to understand the nature of marketing problems as it is only by doing this that workable solution can be found to them. Indeed such knowledge of marketing problems would give information as to why markets are not developing and what measures are required to develop the markets. These problems include the following:

1. Large Number of Middlemen

2. Forced Sales

3. Lack of Transport Facilities

4. Poor handling, Packing, and Processing Facilities

5. Lack of Uniform Standardization and Grading

6. Inadequate Storage Capacity and Warehousing Facilities

7. Adulteration of Produce and Malpractices in Market

8. Growth of Urban Centres

9. Communication Problem

10. Lack of Information about Production and Marketing

11. Small and Scattered Holding

12. Technological Development Problems in Farm Production as asserted by Folarin (2013).

\section{Cooperatives and economic development: issues and lessons}

The cooperative is capable of serving as a vehicle through which economic transformation and improved standard of living can be achieved. These are reflected in its contributions to economic outcomes globally. In its assertion, DTI (2012, p. 18) affirms that experiences the world over have shown that majority of countries whose economies are progressing today have "a vibrant and a dynamic cooperative sector, contributing substantially to the growth of their economies." Cooperatives are vital economic, social actors and environmental actors (Hertig, 2012) since they focus directly on the welfare of their members through provision of affordable services as well as empowering them in different ways within the economies where they operate. The contribution of cooperatives to economic transformation as replicated in its percentage share in nations' gross domestic product (GDP) is significant.

Cooperatives are also important drivers of community development, which translates into development at the national level. They help in the mobilization of local resources and savings, particularly those that are formed by a set of people in the same community for the purpose of meeting their basic needs such as affordable housing or health care services or for a larger community development goals (Zeuli \& Radel, 2005). Furthermore, cooperatives are crucial engines for improved standard of living, particularly in developing world where income gap is wide and the level of poverty is very high. Considering their role in the area of assisting members in the procurement of commodities at affordable rates as well as provision of loan facilities, it is imperative to see how these services have assisted to improve living standard of members and at the same time 
contribute to the growth and development of the economies in which they operate. For example, asides having access to consumable items, many members of the enterprise have been seen to procure vehicles, landed property, buildings, etc. Some have been able to have access to tertiary education through regular loans provided by the society. In addition to these, employment generated by cooperatives has assisted in providing income not only for their employees but also for the society as well as countries of the world.

In a study carried out by lawal, (2009) to assess how cooperatives have contributed to increasing selling and marketing agricultural development in Ojo Local Government Area of Lagos State, Nigeria, it was discovered among other things that cooperatives assisted in the provision of basic amenities and social services in this area. For instance, the study reported that in this locality, 50.9\% of market shades were constructed by cooperatives. Others include: $54.4 \%$ attributed to cooperatives shop; combating social amenities, $74.4 \%$ of markets stores built by them; $47.8 \%$ of recreation centres; $53.3 \%$ jobs created; $67.8 \%$ of capital equipment acquired by them; $45.6 \%$ of sanitation activities carried out by cooperatives; $71.1 \%$ provision of vocational/skills training; $53.3 \%$ of constructed boreholes; provision of storage/processing facilities, $66.7 \%$; $58.9 \%$; procurement of agriculture and equipment inputs for farmers and members, $94.4 \%$ while cooperative involvement in community banking at $61.1 \%$. The above facts underscore the strategic contribution of modern day cooperatives in the process of economic prosperity and improved wellbeing, not only of individual cooperators but also of the overall economy. Some efforts of the Nigerian government at using cooperatives as one of the tools through which development could be achieved are quite commendable. Although, information on the input of the sector in the country are scarce to come by but few ones that are handy indicate that the society's accomplishments in the economy are substantial. In 2012, the Minister of State for Agriculture and Rural Development, Alhaji Bukar Tijani revealed that with the agricultural sector accounting for about $70 \%$ of the nation's workforce, the federal government has put measures in place to use cooperatives in the agricultural sector to boost "rural savings, bumper harvest and additional employment for the youth" (Akinsuyi, 2012). In Nigeria, policies enactments are not major problem, while a good number of them are available more often than not, implementation of policies are always fraught with upheavals. For instance, Agbo (2012a, p. 1) reported that included in the 2007-2009 Medium Term Sector Strategy (MTSS), which aimed at developing the Agriculture and Rural Sector, the federal government of Nigeria assigned the chore of "promoting specialized cooperative societies in the areas of rural infrastructural development, agro-input supply and produce marketing, tractor hire service, enterprise development centres and preservation, processing and storage of fruits, fish, livestock and dairy products." He pointed out that a preliminary assessment of the implementation of the scheme revealed that only 50\% (3 out of the 6 schemes) of the scheme has so far been implemented in the first phase. Government's efforts will only be effective, the sector's contribution to nations' GDP will be enhanced and employment generation as well as provision of income can be replicated in Nigeria.

\section{Recommendation}

For the cooperative societies in Nigeria to perform maximally to be an able to influence sustainable economic development in Nigeria, there must be deliberate efforts to overcome these challenges that cooperative societies are facing in their smooth operations to impact positively in the economy.

Cooperative marketing is the organized sale of farm products and other goods and services on a nonprofit basis in the interests of the individual producer. Cooperative marketing are organized are organized by farmers themselves and the profits are distributed among the farmer-members based on the quantity of the produce marketed by them.

The Cooperative marketing societies should basically ensure that the producer is encouraged to increase production, besides assuring the farmer remunerative prices for his produce and supplying the commodities to the customers at reasonable prices. In view of this, cooperative marketing societies should be established for meeting the requirements of the farmer. The benefits of cooperative marketing include:

- Make arrangement for the sale of produce of the members

- Provides credit facilities to the members on the security of agricultural produce

- Provide grading facilities, which would result in better price

- Make arrangement for scientific storage of the member's produce

- Arrange the supply off inputs required by the member's

- Undertake the system of pooling the produce of the members to enhance the bargaining power through unity of action

- Arrange for the export of the produce to enable the member's and farmers get better returns

- Act as an agent of the government in procurement of food-grains, etc.

Some of the ways to overcome these challenges are suggested and listed below:

(a) Cooperative Education and marketing training: Establishment of a Cooperative Board/Agency:

(b) Improved returns on shares: 
(c) Democratic and transparent Leadership:

(d) Establishment of regulated market

(e) Improvement in storing, handling and packing

(f) Improving transport facilities and

(g) market information and market research

(h) Selling of shares to the Public: as noted Lawal (2009).

\section{Conclusion}

Cooperative societies are very popular in Nigeria and have existed for over a century and have achieved remarkable feats. It has being observed that non-member customers are to encourage to joined and maintain or increase the market share. Leaders of large and well-established Cooperatives believe that their first priority must to be to safeguard existence of the Cooperative marketing enterprise and to enable it to compete in the market, because otherwise no service to members and customers would be possible at all. There are challenges to be considered when approaching a cooperative marketing situation. Both companies must be on the same page when it comes to ideas, promotions, and cash to be made. The marketing purpose must serve both companies accurately and efficiently, as neither brand wants to be compromised by conducting this cooperative effort. Furthermore, there is a certain element of trust and information sharing that must be respected when participating in cooperative marketing efforts. Because the businesses are working together they are seen in the customers eyes as one entity. Trusting one another business to conduct themselves ethically and fairly to customers and employees is an important part to working with one another. Therefore, it is argued that such cooperative marketing enterprises have to work in the same way as their investor-driven, shareholder valueoriented competitors, or lose out to them. . Consequently, the societies becomes numerous and too small in size to be economically viable to significantly influence sustainable economic growth and development in Nigeria.

\section{References}

[1]. Adaji, I.I (2002). "The Relevance of business Association and Cooperative Societies in Nigeria Economic Development" Unpublished paper. National Institute for policy and Strategic studies NIPSS Kuru Jos. $\quad$ pp 55.

[2]. Adeyeye and Ditto (1980). Essential Information on Cooperative Credit Societies (CTCS/CICS). Ibadan: Dac-print Publishers

[3]. Aryeetey, E. and Huha, M (1991). The informal financial sector and markets in Africa: an Empirical study, Econometic Reform in sub-saharan Africa, ed. By Chibber, A and Fisher, S. World Bank symposium, Washington D.C Pp 121.

[4]. Cuevas and Fischer, (2006). Cooperative Financial Institutions: Issues in Governance, Regulation, and Supervision. (C) Washington, DC: World Bank.

[5]. https://openknowledge.worldbank.org/handle/10986/7107

[6]. DiBona, J. (2009) Co-op marketing yields more bang for the buck. Retrieved April 29, 2009, from http://www.sandiego.org/article/Media/267

[7]. Epetimehin, F.M,(2006). Understanding the Dynamics of Cooperatives, ICReTI Publishing House, Ibadan, Nigeria.

[8]. Fred, E (2006), Introduction to Cooperatives, Course Material on COP 101, National Open University of Nigeria, pp1-6.

[9]. Folarin G.S (2013) Discuss the Major problems confronting agricultural marketing in Nigeria a way out. Department of Agricultural Economics and Extension, The Federal University of Techology Akure, Retrieved January 5, 2014, from http://www.

[10]. Helms, F.C (1968). "The Economic of cooperative enterprise" published by Cooperative College, Tanzania in association with University of London Press Ltd Pp.306.

[11]. Lawal, K.A.A and Oludimu, O.L. (2011) Management Principles, Practices and Focus. Ibadan, Asogun Books.

[12]. Lawal, K.A.A (2009)Analysis of managers' roles on performances of cooperative societies in Ojo Local Government Area of Lagos State Nigeria.-M,sc Dissertation Uupublished, Department of Agribusiness and Farm Mangement, Olabisi Onabanjo University, Ago-Iwoye, Ogun State, Nigeria

[13]. Muhammed S.F (2005). "The self-help Groups (SHGS) Linkage banking programme Concept and practice in Nigeria". Abuja CBN Bullion Vol. 29no.4 Oct/Dec. Pp.43-45.

[14]. Nnanna, O.J, Englama, A. and Odoko, F.O ed. (2004). "Financial markets in Nigeria”. Abuja. Central Bank of Nigeria (CBN) Publication. Pp 132-140.

[15]. Onuoha, E. (1978). The History of the cooperative movement in Nigeria. Enugu Nigeria.

[16]. Olesin, A. (2007) The idea of cooperation: Lagos, Grollins Publication.,

[17]. Oludimu, O. L. and Adedoyin, S.F (1996).Running a more successful cooperative, Ijebu Ode: Triumph Book Publishers.

[18]. Reeves, E (2003) The best way of pushing back the limit of economic problems of scarcity: London, Collins Publication.

[19]. Umebali, E. E. (2008), Rural Development and Management, Course Material on MPA769, National Open University of Nigeria, pp36-44

[20]. Webster's College Dictionary; 1991, p300 http://www.ncba.org/abcoop.cfm). 